\title{
KONSEKUENSI NEGARA INDONESIA MENJADI ANGGOTA ICC (Studi Tentang Mekanisme Penegakan Hukum Humaniter Internasional) *
}

\author{
Isplancius Ismail \\ Fakultas Hukum Universitas Jenderal Soedirman \\ E-mail: isplancius@gmail.com.
}

\begin{abstract}
International Humanitarian Law (IHL) is a set of rules which is based on the 1949 Geneva Law and Hague Law in 1907 and equipped with Additional Protocols I and II of 1977. IHL seeks to provide protection to the victims of war and civilians in armed conflict (law of Geneva 1949) and what methods and tools that may be used in war (Hague Law 1907). The parties involved in armed conflict must respect the principles of limitation, proportionality and distinction. Violations of international humanitarian law called war criminals must be prosecuted as crimes against human rights. Enforcement of international humanitarian law carried out through the mechanism according to the 1949 Geneva Law, by temporary or ad hoc Court, and by the International Criminal Court (ICC). The method used in this research is normative qualitative approach by taking secondary data as a source of information. The results indicate that the consequences of Indonesia as a state to be a member of ICC are having the synergy process national law with Rome Statute covering criminal law, criminal procedural law, extradition, human rights court and the law of human rights itself. The final goals of the synergy are to make Rome Statuta as a follow up system of national judicial, to avoid conflict between ICC and the law of Indonesia, and to make internal law procedure for Indonesia when ICC jurisdiction is active in Indonesia.
\end{abstract}

Key words: humanitarian law, war criminal, court jurisdiction

\begin{abstract}
Abstrak
Hukum Humaniter Internasional $(\mathrm{HHI})$ merupakan satu perangkat aturan yang berdasarkan pada Konvensi Jenewa 1949 dan Konvensi 1907 Den Haag 1907 dan dilengkapi dengan Protokol Tambahan 1977. HHI berupaya untuk memberikan perlindungan kepada korban perang/konflik bersenjata dan juga perlindungan bagi penduduk sipil (Konvensi Jenewa 1949) dan mengatur tentang alat dan cara yang boleh digunakan dalam perang (Hukum Den Haag 1907). Para pihak yang terlibat dalam konflik tersebut harus menghormati prinsip-prinsip pembatasan, keseimbangan dan pembedaan. Pelaku pelanggaran terhadap prinsip-prinsip hukum humaniter tersebut disebut penjahat perang. Penegakan hukum humaniter dapat dilakukan dengan melalui mekanisme menurut Konvensi Jenewa 1949, Mahkamah pidana internasional ad doc dan mahkamah kejahatan internasional (ICC). Metode yang digunakan dalam penelitian ini adalah normatif kualitatif dengan menggunakan data sekunder sebagai sumbernya. Hasil penelitian ini menunjukkan bahwa konsekuensi Pemerintah Republik Indonesia apabila menjadi anggota ICC adalah melakukan revisi dalam proses hukum nasionalnya agar dapat sinergi dengan ketentuan yang ada di dalam Statuta Roma 1998 yaitu meliputi hukum pidana nasionalnya, hukum acaranya, ekstradisi, pengadilan HAM dan hukum HAM nya itu sendiri. Tujuan akhirnya adalah membuat Statuta Roma sebagai sistem kelanjutan dari hukum/peradilan nasional sehingga untuk menghindari konflik antara ICC dan hukum nasional Indonesia maka Indonesia harus membuat hukum acara internal ketika ICC aktif di Indonesia.
\end{abstract}

Kata kunci: hukum humaniter, penjahat perang, yurisdiksi pengadilan.

Pendahuluan

Menurut catatan sejarah perang manusia,

* Tulisan ini merupakan hasil penelitian penulis dengan Surat Tugas Dekan Fakultas Hukum Nomor Kept. 013A/ UN23.05/ DT.01.00/2014 tertanggal 3 Januari 2014. pada tanggal 24 Juni 1859 bahwa telah terjadi pertempuran di Solverino dan telah mengakibatkan ribuan prajurit terluka dari pihak Austria dan Perancis. Inisiator Palang Merah Henry Dunant yang dilahirkan di Geneva, Swis pada 
tanggal 8 Mei 1828 sebagai seorang pengusaha sukses terkejut sekali menyaksikan betapa menderitanya para prajurit terluka tanpa daya berbaring sekarat tanpa pertolongan medis. Kenangan buruk tersebut sangat melekat dalam ingatannya dan menggerakkannya untuk menyusun gagasan mengenai Palang Merah mau pun Hukum Humaniter Internasional (HHI). Inti gagasannya adalah bahwa perlu adanya orangorang yang mengorganisir secara sukarela untuk memberikan pertolongan kepada para prajurit yang terluka di medan perang dan perlu ada pengaturan hukum internasional tentang tata cara dan metode perang yang disepakati oleh negara-negara di dunia. Gagasan Henry Dunant tersebut kemudian ditulisnya dalam sebuah buku berjudul A Memory of Solverino (Kenangkenangan mengenai Solferino). Salah satu tonggak penting dalam perkembangan $\mathrm{HHI}$ adalah didirikannya organisasi Palang Merah dan ditandatanganinya Konvensi Jenewa tahun 1864 tentang 'Perbaikan Keadaan Tentara yang Luka di Medan Perang Darat'. Konvensi memperkenankan tanda Palang Merah di atas dasar putih sebagai tanda pengenal bagi bangunan dan personil kesehatan. ${ }^{1}$ Tanda Palang Merah ini merupakan lambang dari International Committee of The Red Cross yang sebelumnya bernama International Committee for The Aid of The Wounded, yang didirikan oleh beberapa orang warga Jenewa dan Henry Dunant pada tahun $1863 .^{2}$

Pada hakikatnya HHI merupakan penghormatan terhadap kemanusiaan, sementara instrumen hukum dirancang untuk memastikan dilakukannya penghormatan terhadap umat manusia dan individu dalam konflik bersenjata, sejauh bahwa hal itu sejalan dengan kebutuhan militer dan ketertiban umum, dan mengurangi penderitaan yang tidak perlu sebagai akibat adanya permusuhan. Perkembangan selanjutnya, bantuan-bantuan diberikan oleh mereka yang terlibat dalam organisasi kemanusiaan ju-

Jean Pictet, 1985, Development And Principles of International Humanitarian Law, Jenewa: Martinus Nijhoff Publisher, hlm. 6.

2 Frits Kalshouven, 1991, Constraint on The Waging of War, Jenewa: Penerbit ICRC, hlm. 7. ga diberikan dalam suasana damai kepada mereka yang menjadi korban akibat bencana alam.

Ketika terjadi perang atau konflik bersenjata pada Perang Dunia I tahun 1913-1918 yang dipicu oleh Jerman dengan tentara Nazinya, para penjahat perang terbukti melanggar $\mathrm{HHI}$ seperti Hermann Wilhelm Goering, mantan pejabat Nazi telah dijatuhi hukuman oleh tentara Sekutu sebagai pihak pemenang perang melalui Mahkamah Nurenberg saat itu. Namun sistem peradilan yang dilakukan di Nurenberg masih berdasarkan keadilan menurut versi pihak pemenang perang (Victor's Justice). ${ }^{3}$ Perang Dunia I diakhiri dengan dibentuknya Liga Bangsa Bangsa berdasarkan perjanjian Versailes tahun 1919. Dalam perjalanan sejarah dunia terbukti bahwa Liga Bangsa Bangsa ini gagal menciptakan perdamaian dunia ketika Jepang memicu kembali Perang Dunia II pada tahun 1939-1945 karena ingin mengembangkan kembali kekuasaan imperium/kekaisaran ${ }^{4}$.

Perang Dunia II ini akhirnya berakhir ketika kota Hirosima dan Nagasaki dijatuhi bom atom oleh tentara sekutu dan pada saat perang berhasil dibentuk Perserikatan Bangsa Bangsa pada tanggal 26 Juni 1945 di San Fransisco. Para penjahat perang pun telah dijatuhi hukuman setelah diadili di Tokyo. HHI disempurnakan dengan dibuatnya empat Konvensi Jenewa 1949 yang mencakup perlindungan terhadap korban perang/konflik bersenjata di darat, di laut, tawanan perang dan perlindungan penduduk sipil. Demikian pula protokol tambahan I dan II tahun 1977 sebagai peleng-kap Konvensi Jenewa 1949 dan juga Konvensi Den Haag 1907 yang mengatur tentang cara/metode serta alat yang boleh digunakan dalam berperang dan khususnya ditujukan kepada para komandan perang.

Indonesia sebagai negara yang telah mengaksesi Konvensi Jenewa 1949 dengan Undang-Undang Nomor 59 tahun 1958 mempunyai

Arie Siswanto, 2005, Yurisdiksi Material Mahkamah Kejahatan Internasional, Jakarta: Ghalia Indonesia, hlm. 10.

4 Jawahir Thantowi, "Pelanggaran HAM Berat", Jurnal Hukum, Vol. 14 No. 2 Edisi 2004, Semarang: Penerbit Fakultas Hukum Universitas Islam Sultan Agung, hlm. 289. 
kewajiban menghormati Konvensi Jenewa 1949. Adapun Konvensi Den Haag 1907 sudah menjadi kebiasaan internasional sehingga semua negara harus dianggap terikat dengan kebiasaan internasional tersebut sehingga ketika terjadi pelanggaran terhadap tindakan pidana HAM berat setiap negara yang berdaulat berkewajiban untuk melakukan penegakan HHI. Jika negara tidak mampu dan tidak mau melakukan kewajibannya, maka tanggung jawabnya akan diambil alih oleh masyarakat internasional. ${ }^{5}$ Penegakan hukum humaniter internasional guna mengadili para pelanggar HAM berat/penjahat perang ini dapat dibedakan menjadi tiga mekanisme, yaitu, pertama, menurut Konvensi Jenewa 1949, kedua, dengan peradilan sementara (ad hoc) yang bersifat kasuistis, dan ketiga, dengan menggunakan Mahkamah Pidana Internasional (International Criminal Court/ICC).

\section{Permasalahan}

Indonesia sebagai negara berdaulat dan memiliki yurisdiksi nasional terhadap pelaku kejahatan HAM berat yang terjadi di wilayah yurisdiksinya pada awalnya telah merencanakan akan meratifikasi Statuta Roma 1998 dalam arti ada keinginan menjadi anggota ICC pada tahun 2008. Akan tetapi rencana tersebut dijadwalkan kembali tahun 2013 dan sampai sekarang belum ada kejelasan tentang ratifikasi terhadap Statuta tersebut. Dalam konteks penegakan $\mathrm{HHI}$ di Indonesia permasalahannya dapat dirumuskan sebagai berikut: bagaimana konsekuensi negara dalam arti langkah-langkah apa yang harus dilakukan Indonesia apabila menjadi anggota ICC?

\section{Metode Penelitian}

Penelitian ini dilakukan dengan menggunakan metode pendekatan kualitatif dengan data sekunder sebagai sumber informasi, baik berupa bahan hukum primer maupun bahan hukum sekunder. Data sekunder yang digunakan berupa bahan hukum primer yaitu bahanbahan yang bersumber dari ketentuan hukum

Isplancius Ismail, 2011, Konsep Dasar Hukum Internasional, Purwokerto: UPT Percetakan dan Penerbitan Universitas Jenderal Soedirman, hlm. 78. yang ada kaitannya dengan hukum humaniter internasional berupa Konvensi Den Haag 1907, Konvensi Jenewa 1949, Protokol-protokol tambah I dan II tahun 1977. Sementara bahan hukum sekunder yaitu bahan-bahan yang bersumber dari pendapat ilmiah para sarjana dan buku-buku literatur yang ada kaitannya hukum humaniter internasional yang diperoleh dengan cara melakukan inventarisasi terhadap buku literatur, dokumen, artikel, dan berbagai bahan yang telah diperoleh, dicatat kemudian dipelajari berdasarkan relevansi-relevansinya dengan pokok permasalahan yang diteliti, dan selanjutnya dilakukan pengkajian sebagai satu kesatuan yang utuh.

\section{Pembahasan}

Pengertian dan Ruang Lingkup Hukum Humaniter Internasional

$\mathrm{HHI}$ adalah seperangkat aturan yang karena alasan-alasan kemanusiaan berusaha untuk membatasi pengaruh atau akibat konflik bersenjata. Hukum humaniter ini melindungi orang-orang yang tidak, atau tidak lagi ikut serta dalam pertempuran dan membatasi sarana dan cara-cara peperangan. ${ }^{6}$ Istilah yang pertama dikenal dikalangan militer adalah hukum perang (The Law of War) atau hukum sengketa bersenjata (The Law of Armed Conflict), sementara itu di kalangan Palang Merah dan Bulan Sabit Merah lebih sering menyebut istilah Hukum Perikemanusiaan Internasional (HPI). Istilah Hukum Sengketa Bersenjata mengalami perubahan lagi yaitu diganti dengan istilah Hukum Humaniter Internasional (International Humanitarian Law) yang berlaku dalam sengketa bersenjata dan selanjutnya disebut $\mathrm{HHI}^{7}$

Asal usul HHI dapat ditemukan dalam peraturan hukum dan aturan agama serta kebudayaan di seluruh dunia dan dalam perkembangan modern dari hukum ini dimulai pada abad ke19. Sejak abad tersebut negara-negara menye-

6 Sumaryo Suryokusumo, "Agresi Dalam Perspektif Hukum Internasional”, Jurnal Hukum Internasional, Vol.3, No. 1 Edisi 2005, Jakarta: Penerbit Lembaga Pengkajian Hukum Internasional UI, hlm. 33.

7 Arlina Permanasari dkk, 1999, Pengantar Hukum Humaniter Internasional, Jakarta: Penerbit ICRC, hlm. 8. 
tujui seperangkat aturan-aturan praktis yang didasarkan pada pengalaman pahit dari peperangan modern yang merupakan perimbangan hati-hati antara kepedulian kemanusiaan dan kebutuhan militer negara-negara.

$\mathrm{HHI}$ melarang semua sarana dan metoda peperangan yang gagal untuk membedakan antara orang-orang yang ikut serta dalam pertempuran dan penduduk sipil, yang tidak ikut serta dalam pertempuran; dan menyebabkan luka yang berlebihan atau penderitaan yang tidak perlu; menyebabkan kerugian berat atau berkepanjangan terhadap lingkungan. Dengan demikian $\mathrm{HHI}$ melarang penggunaan banyak senjata termasuk peluru yang bisa meledak (peluru dum-dum), senjata bio kimia, biologis, nuklir, senjata laser yang membutakan mata dan ranjau anti-personil. HHI mencakup 2 (dua) bidang yaitu perlindungan kepada orang-orang yang tidak, atau tidak lagi ikut serta dalam pertempuran (horse de combat); dan pembatasan terhadap sarana peperangan, terutama senjata, dan metoda-metoda peperangan, seperti misalnya taktik-taktik militer.

\section{Prinsip Dasar dan Komponen Gerakan Palang Merah dan Bulan Sabit Merah \\ Komponen Gerakan Palang Merah dan Bu-} lan Sabit Merah terdiri dari International Committee of the Red Cross (ICRC), Federasi Palang Merah dan Bulan Sabit Merah dan Perhimpunan Palang Merah Nasional. Prinsip dasar Gerakan Palang Merah dan Bulan Sabit Merah ada 7 (tujuh) yaitu: kemanusiaan; kesamaan (dalam membantu korban); kenetralan (dalam menghadapi konflik); kemandirian; kesukarelaan, kesatuan (hanya boleh ada satu perhimpunan palang merah dalam suatu negara), dan kesemestaan (sama dan setara di seluruh dunia).

Jika dibandingkan dengan ketentuan ajaran Islam memandang peperangan, maka hal tersebut diperbolehkan hanya didasarkan pada alasan: pertahanan diri, membantu orang yang sedang disiksa, atau mendirikan keadilan (kebenaran). ${ }^{8}$ Dalam kaitannya dengan hukum hu-

8 Abubakar Al-Yasa, "Prinsip-prinsip Hukum Humaniter dalam Hukum Islam”, Jurnal IImu Hukum Kanun, Vol. 9 maniter maka Abubakar Al-Yasa berpendapat bahwa beberapa prinsip Islam dalam berperang yaitu: pertama, prajurit dilarang meng-ganggu orang dan merusak diri barang-barang mereka; kedua, senjata harus digunakan secara proporsional; ketiga, para prajurit yang kalah menjadi sandera dan tidak bisa dibunuh; dan keempat, hukum harus selalu dihormati.

Terdapat kemiripan prinsip antara ajaran Islam dengan ketentuan dalam ICRC meskipun dengan formulasi yang berbeda. Ada beberapa prinsip-prinsip yang harus dihormati oleh para pihak yang terlibat dalam HHI menurut ICRC. Pertama, dalam situasi perang, penghormatan harus ditujukan terhadap setiap orang dan martabatnya; kedua, hak dari semua pihak yang terlibat dalam konflik/sengketa bersenjata untuk memilih sarana dan metoda perang adalah tidak tak terbatas (Prinsip Pembataan); ketiga, harus ada hubungan yang wajar atau seimbang antara operasi yang dicapai dan biaya atau modal yang dikerahkan dengan memperhitungkan kematian, kehancuran dan penderitaan manusia (Prinsip Proporsional); dan keempat, pembedaan harus dijaga pada semua waktu antara sasaran serangan yang sah dan tidak sah (Prinsip Pembedaan).

\section{Perlindungan Hukum Humaniter Internasional}

Secara prinsip $\mathrm{HHI}$ melindungi orangorang yang tidak ikut serta dalam pertempuran, seperti misalnya penduduk sipil, petugas medis dan rohaniawan keagamaan, orang-orang yang terluka, orang yang mengalami kapal rusak, orang sakit, dan tawanan perang. ${ }^{9}$ Orangorang yang dilindungi adalah mereka yang tidak boleh diserang, harus terhindar dari pelanggaran fisik dan perlakuan yang tidak manusiawi,

No. 24 Edisi 1999, Aceh: Penerbit Fakultas Hukum Universitas Syiah Kuala, hlm. 350; Nurdin Ridwan, "Perlindungan Korban Perang menurut Hukum Humaniter dan Hukum Islam" Jurnal Ilmu Hukum Kanun, Vol. 9 No. 24 Edisi 1999, Aceh: Penerbit Fakultas Hukum Universitas Syiah Kuala, hlm. 370.

9 Devy Sondakh, “Aspek-aspek Hukum Humaniter dalam Kejahatan Perang yang Dilakukan oleh Anggota Dinas Angkatan Laut dalam Konflik Internasional" Jurnal Hukum Humaniter, Vol. 4 No. 7 Edisi 2008, Jakarta: Penerbit Pusat Studi Hukum Humaniter dan HAM Universitas Trisakti, hlm. 1256. 
terluka dan sakit yang harus dikumpulkan dan mendapat perawatan. Aturan terperinci termasuk ketentuan mengenai pangan dan papan yang memadai serta jaminan hukum berlaku bagi orang-orang yang menjadi tawanan atau ditahan. Adapun tempat dan obyek yang dilindungi dan tidak boleh diserang, antara lain rumah sakit, museum dan ambulans.

$\mathrm{HHI}$ mengeluarkan sejumlah lambang dan tanda-tanda yang dapat dilihat dengan jelas, yang dapat dipakai untuk mengidentifikasi orang-orang, tempat-tempat dan obyek yang dilindungi. Lambang dan tanda itu termasuk Palang Merah dan Bulan Sabit Merah. Lambang tersebut ada yang berukuran besar yang bermakna sebagai tanda perlindungan, dan lambang yang berukuran kecil digunakan untuk tanda identitas bahwa si pemakai tanda tersebut beraktivitas terkait dengan tugas-tugas kemanusiaan.

\section{Sumber Hukum Utama HHI}

Terdapat tiga sumber hukum utama $\mathrm{HHI}$ yang dapat dijadilan dasar hukum yaitu Hukum Jenewa 1949, Hukum Den Haag 1967 dan hukum campuran. Pertama, Hukum Jenewa 1949 terdiri dari 4 (empat) Konvensi, yaitu: Konvensi Jenewa I tentang Perlindungan korban yang luka/sakit akibat perang di Darat; Konvensi Jenewa II tentang Perlindungan korban yang luka/ sakit atau kapal karam akibat perang di laut; Konvensi Jenewa III tentang Tawanan Perang; dan Konvensi Jenewa IV tentang Perlindungan terhadap Penduduk Sipil.

Kedua, Hukum Den Haag 1907, yaitu lebih ditujukan kepada para komandan dan mengatur tentang sarana dan cara-cara/metode yang dibenarkan dalam peperangan. Ketiga, hukum campuran, yaitu berupa Protokol Tambahan I dan II tahun 1977 yang dibuat dan isinya untuk melengkapi baik Konvensi Jenewa 1949 maupun Konvensi Den Haag 1907. Protokol Tambahan I lebih banyak mengatur tentang sengketa bersenjata yang bertaraf internasional dimana pihak-pihak yang terlibat adalah negara-negara, termasuk perang pembebasan nasional, sedangkan Protokol Tambahan II lebih banyak meng- atur tentang sengketa bersenjata yang bertaraf non-internasional.

Protokol I menetapkan batasan-batasan sejauh mana operasi militer boleh dilakukan dan pendudk sipil berhak atas perlindungan dari pengaruh-pengaruh peperangan, sedangkan Protokol II menetapkan bahwa orang-orang yang terluka harus dilindungi dan mendapat perawatan, selain itu tenaga dan transpor medis harus dilindungi dan dihormati. Demikian pula lambang Palang Merah dan Bulan Sabit Merah harus dihormati, serta penggunaannya harus dibatasi pada orang-orang yang berwenang untuk memakainya. Pelanggaran terhadap larangan menyerang pada penduduk sipil, objek-objek yang sangat perlu bagi kelanjutan keselamatan penduduk, objek-objek budaya dan tempat peribadatan, pabrik dan instalasi yang mengandung kekuatan yang berbahaya serta lingkungan hidup dianggap sebagai pelanggaran berat terhadap HHI dan diklasifikasikan sebagai kejahatan perang (pelakunya disebut sebagai 'penjahat perang').

Menurut Hagan ${ }^{10}$ seperti dikutip Chairil Anwar Adji bahwa kekerasan yang dilakukan negara berwujud pada: pelanggaran hak asasi manusia (violation of human rights); pengekangan kedaulatan rakyat (civil liberties); penguasa melakukan legalisasi terhadap penyimpangan yang dilakukan dan mempertahankan status quo (maintaining the status quo); kekerasan aparat yang terselubung dan direncanakan (secret police viola-tions); kekerasan kemanusiaan (human right abuse); dan pembunuhan massal (genocide) merupakan beberapa contoh kekerasan yang dilakukan negara.

\section{Mekanisme Implementasi Penegakan HHI}

Penegakkan $\mathrm{HHI}$ terhadap pelaku kejahatan perang dapat dilakukan dengan beberapa mekanisme yaitu mekanisme menurut Konvensi Jenewa 1949, Peradilan Ad Hoc dan berdasarkan Mahkamah Peradilan Internasional. Pertama, menurut Konvensi Jenewa 1949, bahwa

10 Hagan dalam Chairil Anwar Adjis, "Peradilan Internasional Versus Bush: Studi Kasus State Violence", Jurnal Kriminologi Indonesia, Vol. 3 No. 1 Edisi Juni 2012, Jakarta: Departemen Kriminologi UI, hlm. 26. 
negara yang telah menjadi peserta dalam Konvensi Internasional $\mathrm{HHI}$ apabila mendapati warganya yang melakukan kejahatan perang maka wajib menangkapnya, melakukan penyelidikan dan menjatuhi hukuman sesuai hukum nasionalnya.

Kedua, melalui Peradilan Ad Hoc dilakukan yaitu apabila mekanisme pertama tidak dapat dijalankan sehingga kewajiban tersebut kemudian diambil alih oleh masyarakat internasional dalam hal ini PBB khususnya melalui Dewan Keamanan. Dewan ini membentuk peradilan yang bersifat sementara atau kasuistis seperti yang pernah dilakukan terhadap Negara Rwanda dengan International Criminal Tribunal for Rwanda (ICTR) dan terhadap Yugoslavia dengan International Criminal Tribunal for the Former Yugoslavia (ICTY) pada tahun 1993.

Ketiga, berdasarkan Mahkamah Peradilan Internasional atau International Criminal Court (ICC), yaitu mekanisme baru yang dirancang melalui perjanjian internasional yang dibentuk di Roma dan disebut Statuta Roma 1998. Peradilan atau Mahkamah ini terpisal dari Perserikatan Bangsa Bangsa (PBB) dan bersifat komplementer. Keberadaan ICC dimaksudkan untuk mencegah terulangnya kembali peradilan yang bersifat Victor's Justice, Selective Justice dan Impunity (yang hanya berdasarkan keadilan negara yang menang perang). Apabila negara sudah tidak mau dan tidak mampu mengadili si pelaku kejahatan perang, maka akan diadili oleh ICC tanpa diskriminasi yaitu tidak memandang apakah pelaku kejahatan perang itu berasal dari negara besar atau negara kecil. Selain itu ditopang teori umum hukum internasional bahwa agar suatu negara terikat dengan lembaga ICC, maka negara tersebut harus terlebih dahulu meratifikasi Statuta Roma 1998. ${ }^{11} \mathrm{Hal}$ yang masih perlu diteliti lebih lanjut adalah kapankah suatu hukum (tertulis) berubah menjadi hukum kebiasaan internasional, sehingga konsekuensinya hukum kebiasaan tersebut secara otomatis mengikat suatu negara. Ketidak-

11 Melda Kamil Ariadno, "Kedudukan Hukum Internasional dalam Sistem Hukum Nasional" Jurnal Hukum Internasional, Vol. 5 No. 3 Edisi 2008, Jakarta: Lembaga Pengkajian Hukum Internasional UI, hlm. 515. jelasan pemberlakukan kebiasaan internasional inilah yang seringkali selalu mengenabalikan pemberlakuan hukum internasional selalu harus dengan ratifikasi. ${ }^{12}$

\section{Konsekuensi Hukum bagi Indonesia Sebelum Meratifikasi ICC}

Sudah menjadi rahasia umum bahwa terdapat keraguan politik dari Pemerintah Indonesia untuk meratifikasi ICC karena sifat ICC yang supranasional dan ditakutkan akan melanggar kedaulatan Hukum Indonesia. ${ }^{13} \mathrm{Hal}$ inilah yang menjadi alasan utama keberadaan ICC menghadapi banyak tantangan di Indonesia bahkan dari kalangan pemerintah sendiri. ${ }^{14} \mathrm{Ke}$ tidakinginan pemerintah untuk menjadi anggota ICC terbukti lewat ketidakpastian proses ratifikasi Statuta Roma di Indonesia yang sebenarnya sudah direncanakan sejak tahun 2004. Pada Maret 2003 dengan kunjungan terakhir delegasi Pemerintah Indonesia ke markas ICC di Den Haag, Belanda memunculkan rencana ratifikasi mengemuka kembali. Namun keraguan Indonesia meratifikasi nampak ketika Indonesia menjalani proses pemilu 2014 yang dapat berujung pada perubahan rezim sehingga pemerintah baru nanti akan berpikir ulang untuk melakukan ratifikasi ICC yang akan mempunyai dampak besar karena membawa konsekuensi tanggung jawab yang besar pula terhadap komitmen penegakan HAM. ${ }^{15}$ ICC akan berjalan dengan baik di Indonesia apabila Indonesia melakukan langkah-langkah sehingga terjadi sinergi antara Statuta Roma ke dalam Undang-Undang Negara

12 Sefriani, "Ketaatan Masyarakat Internasional terhadap Hukum Internasional dalam Perspektif Filsafat Hukum" Jurnal Hukum, Vol. 18 No. 3 Edisi 2011, Yogyakarta: Fakultas Hukum Universitas Islam Indonesia, hlm. 420.

13 Wisnu Aryo Dewanto, "Memahami Arti Undang-undang Pengesahan Perjanjian Internasional di Indonesia", Jurnal Opinio Juris, Vol. 4 Edisi Januari-April 2012, Jakarta: Direktorat Jenderal Hukum dan Perjanjian Internasional $\mathrm{hlm} .22$.

14 Aristo, op.cit., hlm. 134, 139-140.

15 Supancana, "Kemungkinan Meratifikasi Protocol of Space Asset: Pertimbangan dan Implikasinya Kepada Kepentingan Nasional" Jurnal Analisis dan Informasi Kedirgantaraan, Vol. 4 No. 1 Edisi 2007, Jakarta: Lembaga Penerbangan dan Antariksa Nasional, hlm. 17; Novianti, "Implikasi Ratifikasi Protokol Kyoto terhadap Pengelolaan Hutan Indonesia" Percikan, Vol. 109 Edisi 2010, Bandung: Penerbit Ikatan Keluarga Besar Universitas Jambi, hlm. 31. 
Indonesia mencakup hukum pidana, ekstradisi, pengadilan HAM dan Undang-Undang HAM itu sendiri dan utamanya adalah hukum acara pidananya yang berpotensi menimbulkan konflik. ${ }^{16}$

Mengingat tujuan akhir dari sinergi tersebut adalah untuk memberlakukan Statuta Roma sebagai perpanjangan sistem yudisial nasional Indonesia; untuk mencegah potensi konflik antara ICC dan Undang-Undang negara Indonesia dan untuk membuat prosedur internal hukum acara bagi Indonesia pada saat yurisdiksi ICC aktif di Indonesia. ${ }^{17}$ Agar sinergi tersebut dapat berjalan dengan baik di Indonesia maka perlu melakukan revisi terhadap seluruh peraturan yang ada berdasarkan pada permasalahan spesifik yaitu kedaulatan dan komplementaritas seperti ne bis in idem, penyerahan subjek hukum yang tunduk kepada hukum Indonesia kepada ICC, masalah imunitas, disparitas pemidanaan hingga masalah praktisi hukum di ICC. Di samping itu, Indonesia juga perlu membuat satu Undang-Undang baru secara khusus yaitu Undang-Undang kerjasama dengan ICC atau yang dalam praktik negara disebut dengan Cooperation Act. ICC dalam melaksanakan hal ini akan berkontribusi besar dalam memberantas kejahatan HAM berat dengan memberikan insentif kepada yurisdiksi Nasional Indonesia terlebih dahulu dan pada saat bersamaan, mengambil peran sebagai Safety net (jaring pengaman) kepada yurisdiksi nasional melalui asas komplementaritas ICC. ${ }^{18}$ Seperti dikatakan Payam Akhavan bahwa, "pursuing international justice can translate into enhanced domestic law enforcement efforts" ${ }^{19}$. Memang harus diakui di-

16 Wisnu Aryo Dewanto, "Status Hukum Internasional dalam Sistem Hukum di Indonesia", Jurnal Mimbar Hukum, Vol. 21 No. 2 Edisi 2009, Yogyakarta: Fakultas Hukum UGM, hlm. 335.

17 Harianja Nalesti Trihoni, "Pertanggungjawaban Pidana secara Individual bagi Pelanggaran Hukum Humaniter dalam Konflik Bersenjata Internal”, Jurnal Hukum Respublica, Vol. 3 No. 2 Edisi 2004,Pekanbaru: Fakultas Hukum Universitas Lancang Kuning, hal. 149.

18 Heru Cahyono, "Kejahatan Perang yang Diatur dalam Hukum Internasional dan Hukum Nasional", Jurnal Hukum Humaniter, Vol. 1 No. 1 Edisi 2005, Jakarta: Pusat Studi Hukum Humaniter dan HAM Universitas Trisakti, hlm. 136.

19 Payam Akhavan, “The Lord's Resistance Army Case: Uganda's Submission of the First State Referral to the International Criminal Court," American Journal of In- perlukannya perlengakapan pemaksa untuk melakukan esekusi dari dalam negeri, hal ini dikarenakan keterbatasan yang dipunyai ICC seperti yang dinyatakan dalam hal ketidak-cukupan kelengkapan institusi dalam tubuh ICC itu sendiri dan kekuatan politik jika tidak ditaati aturanaturan ICC tersebut. ${ }^{20}$

\section{Kasus: Keterlibatan Amerika di Irak}

Salah satu agenda utama AS menolak meratifikasi ICC adalah karena AS kerap kali melakukan invasi ke negara lain, salah satunya adalah menginvasi Irak. AS ingin menghindar dari tuduhan sebagai subyek pelaku kejahatan internasional oleh ICC. ${ }^{21} \mathrm{Hal}$ ini dilakukan AS untuk menghindari berbagai tuduhan bagi pejabatnya, seperti melanggar konvensi PBB, pembantaian besar-besaran, terbunuhnya rakyat sipil, melanggar aturan internasional, melanggar kedaulatan sebuah negara dan aneka tuduhan lain nya, yang akan membuat AS berada pada posisi terpojok tanpa sanggup membeberkan fakta secara rasional. AS tidak mau mengalami nasib seperti Jepang yang negaranya harus bertanggungjawab karena negaranya dikategorikan sebagai penjahat perang. ${ }^{22}$ Sikap penolakan AS untuk meratifikasi ICC tersebut terbukti ketika AS gencar sibuk melakukan diplomasi ke berbagai negara untuk mendapatkan perlunya dilakukan serangan militer terhadap Irak dengan tanpa mengindahkan upaya tim inspeksi PBB yang menyelidiki bukti Irak menyimpan senjata pemusnah atau tidak. Niat untuk menghancurkan Irak dapat diketahui dari pernyataan pejabat AS Richard Perle, Kepala Komisi Kebijakan dan Pertahanan Pentagon, di Surat Kabar Daily Te-

ternational Law, Vol. 99 Edisi April 2005, Washington: American Society of International Law, hlm. 409.

20 Sri Yuniati, "Hukum Humaniter Internasional atas Kejahatan Perang" Jurnal Ilmu Sosial Dan Ilmu Politik Aspirasi, Vol. 16 No. 1 Edisi 2006, Jember: Fakultas Ilmu Sosial dan Ilmu Politik Universitas Jember, hlm. 27.

21 Chairil Anwar Adjis, "Peradilan Internasional Versus Bush: Studi Kasus State Violence", Jurnal Kriminologi Indonesia, Vol. 3 No 1 Edisi Juni 2012, Jakarta: Departemen Kriminologi UI, hlm. 25.

22 Dewi Savitri, "Kejahatan Perang Oleh Jepang: Studi Kasus Terhadap Jugung lanfu Sebagai Hegemoni Kebudayaan di Indonesia Periode 1942-1945" Jurnal Kriminologi Indonesia, Vol. 6 No. 3 Edisi 2010, Jakarta: Departemen Kriminologi UI, hlm. 279; Sri Yuniati, op. cit, hlm. 30. 
legraph yang mengatakan bahwa AS akan menyerang sendirian tanpa harus mendapat lisensi apapun dari PBB, Ricard ${ }^{23}$ menyatakan, bahwa:

"Saya tidak ragu dia (Bush) akan bertindak sendirian jika perlu. Tetapi saya kira dia tidak akan sendirian jika waktu serangan itu tiba. Saya yakin Inggris akan bergabung."

AS akhirnya menyerang Irak dengan mengatas namakan masyarakat internasional, tetapi hal tersebut harus dilakukan sesuai dengan hukum internasional. ${ }^{24}$ Sementara serangan ke Irak dilakukan tanpa mengindahkan ketentuan Chapter II UN Security Council dimana ditentukan bahwa Dewan Keamanan PBB diperbolehkan untuk "determine the existence of any threat to the peace, breach of the peace, or act of aggression, and to take military and nonmilitary action to "restore international peace and security". Ini berarti tidak ada satu negara atau pun kelompok negara-negara yang bisa bertindak atas nama masyarakat internasional tanpa adanya mandat dari Dewan Keamanan PBB. Kalau tidak ada mandat maka dapat dikatakan terjadi apa yang disebut sebagi agresi sesuai ketentuan dalam Chapter II Dewan Keamanan PBB tersebut. ${ }^{25}$ Terhadap keterlibatan AS apakah dapat digolongkan sebagai State violence atau tidak, maka dipinjam konsep Hagan yang sudah dikemukakan terdahulu sehingga terdapat beberapa hal yang perlu digarisbawahi berkaitan konflik AS dan Irak yang dijelaskan pada bagian di bawah ini. ${ }^{26}$

\section{Violation of Human Rights}

Kekerasan negara merupakan perilaku kekerasan yang berakibat terenggutnya hak asasi manusia secara keseluruhan. Akibat dari state violence mempunyai implikasi penderitaan yang

23 Ibid.

24 Achmad Yulianto, "Penempatan Pasukan Amerika Serikat di Selat Malaka Perspektif Hukum Internasional" Jurnal Media Hukum, Vol.12 No.1 Edisi 2005, Yogyakarta: Penerbit Fakultas Hukum Universitas Muhammadiyah Yogyakarta, hlm.27.

25 Sumaryo Suryokusumo, “Agresi Dalam Perspektif Hukum Internasional”, Jurnal Hukum Internasional, Vol. 3 No. 1 Edisi 2005, Jakarta: Penerbit Lembaga Pengkajian Hukum Internasional Universitas Indonesia, hlm. 29-47.

26 Chairil Anwar Adjis, op.cit, hlm. 29. beragam dimana bertahun-tahun rakyat Irak menderita akibat embargo ekonomi. Invasi AS terhadap Irak telah memberangus hak asasi bangsa Irak, rakyat Irak telah kehilangan hak asasinya untuk hidup, bekerja, menafkahi keluarga, hak suara, hak kebebasan, hak sekolah, dan hak mensejahterakan anak-anak. Anak, istri, ibu, ayah mereka mati terkena bom. Hak bangsa Irak sebagai negara berdaulat nyaris punah. Tidak ada pelindung bagi rakyat Irak, tidak ada juga polisi atau kantor publik yang melayani keluh kesah mereka. Siang malam diselimuti ketakutan terjadinya serangan AS dan ketika invasi AS terjadi, bangsa Irak bersiap mempertahankan kedaulatan negerinya dari ancaman asing dengan nyawa sebagai taruhannya. Kedaulatan mereka dipertaruhkan secara fisik, setelah bertahun-tahun kedaulatan mereka juga diinjak-injak secara ekonomis oleh Amerika Serikat.

\section{Genocide (Genosida)}

Akibat logis dari kekerasan negara adalah terjadinya pembunuhan rakyat sipil, baik disengaja maupun tidak. Hal ini terjadi karena pembantaian rakyat, seperti terkena peluru nyasar, salah sasaran, bom yang tidak akurat dan menginjak ranjau merupakan kejahatan puncak dari kejahatan yang dilakukan negara (ultimate violent crime by the government).

Sejak Perang Teluk terjadi, sejumlah lebih dari 600.000 anak di Irak telah mati karena kekurangan makanan dan obat-obatan akibat embargo ekonomi. Saat AS menggempur Irak, ratusan orang dikabarkan mati dan ribuan lagi hilang, seperti dikutipoleh Chairil Anwar Adjis dari siaran TV Al-Jazeera yang ditayangkan tanggal 27 Maret 2003. AS salah sasaran karena menyerang pasar yang menewaskan 15 orang, diantaranya anak kecil yang masih bertahan hidup dengan usus terburai akibat serpihan bom yang dilakukan $\mathrm{AS}^{27}$ Akibatnya banyak nyawa manusia melayang meskipun alasan legitimasi penyerangan ke Irak memproduksi senjata masal tidak terbukti. Konsekuensi logisnya adalah kekerasan negara (AS) adalah terjadinya geno-

27 Ibid. hlm. 30. 
sida yang pelakunya berdasarkan prinsip ICC yang netral harus diseret ke Mahkamah Internasional sebagai penjahat internasional.

Terhadap permasalahan siapa yang harus bertanggungjawab atas terjadinya kejahatan perang yang dilakukan antar atau dalam suatu negara, maka bisa dilihat pada doktrim tanggungjawab komando yang sudah ada sejak sebelum PD II. ${ }^{28}$ Beberapa praktik masyarakat internasional pasca Perang Dunia II semakin mengukuhkan eksistensi doktrin ini dalam hukum internasional. Doktrin ini kemudian dikodifikasikan ke dalam Konvensi dan Protokol di bidang HHI, Statuta Pengadilan I Internasional Ad hoc di bekas Yugoslavia dan Rwanda serta Statuta Mahkamah Pidana Internasional. Adapun sifat pertanggungjawaban komando dapat di bedakan menjadi tanggungjawab yang bersifat: langsung (direct command responsibility); dan tidak langsung (indirect command reponssibility).

Dinamika perkembangan doktrin tanggungjawab komando menunjukkan adanya pergeseran penerapan standar mens rea (unsur kesengajaan) dari pertanggungjawaban yang mutlak (strict liability) kepada pertanggungjawaban yang terbatas (limited liability). Meskipun terdapat variasi dalam praktik internasional dan nasional, dikenal tiga unsur utama dari doktrin tanggung jawab komando, yaitu: unsur hubungan antara atasan dan bawahan; unsur kesengajaan (mens rea), dan unsur tindakan yang diharuskan (actus reus) ${ }^{29}$.

Mendasarkan pada pendapat Soerjono Soekanto tentang lima sebab terjadinya kejahatan perang, Mulyana W. Kusumah menyiampulkan bahwa meski tidak terbukti Irak memproduksi senjata masal, ternyata ada enam alasan AS tetap menyerang Irak..$^{30}$ Pertama, adanya orientasi mendapatkan materi dengan jalan mudah. Minyak merupakan pertimbangan eko-

28 Natsri Anshari, "Tanggung Jawab Komando Menurut Hukum Internasional dan Hukum Nasional Indonesia" dalam Jurnal Hukum Humaniter, Vol. 1 No. 1 Edisi 2005, Jakarta: Pusat Studi Hukum Humaniter dan HAM Universitas Trisakti, hlm. 49.

29 Ibid, hlm. 50.

30 Mulyana W. Kusuma, 1990, Analisa Kriminologi Tentang Kejahatan-Kejahatan Kekerasan, Jakarta: Ghalia Indonesia, hlm. 7. nomis yang dipandang strategis pada era teknologi. Potensi sumberdaya alam Irak tak meragukan lagi, sebagai barometer minyak dunia, di samping negara arab lainnya. Kedua, tidak adanya penyaluran kehendak serta adanya semacam tekanan mental pada seseorang. Konflik AS-Irak adalah konflik pribadi Bush. Meski kadar hanya personal, bagi Bush masalah tersebut sangat serius dan sangat mungkin masalah "pribadi" tersebut yang menguasai frame of referrence sebagai presiden untuk menentukan kebijakan nasional dan internasional. Ketiga, keberanian mengambil resiko. Keempat, sebagai negara adikuasa, AS memiliki self confidence yang tinggi dan tahu bahwa PBB memberi porsi istimewa terhadapnya dalam segala hal seperti: politik, ekonomi, budaya beserta semua kebijakan internasional. Kelima, kurangnya perasaan bersalah, amerika Serikat meyakini serangannya terhadap Irak memiliki banyak tujuan positif bagi kepentingan nasional dan internasional. Untuk tujuan nasional, Amerika akan mengalami perbaikan ekonomi signifikan melalui hegemoni minyak dunia. Adapun manfaat bagi dunia internasional, menurut AS adalah terjaminnya demokrasi dunia secara menyeluruh, memberi rasa aman bagi negara tertentu (Israel dan Kuwait) dan menggulingkan rejim berbahaya seperti Saddam Hussein. Keenam, adanya keteladanan yang kurang baik. George W. Bush berasal dari keluarga presiden dimana ayahnya sendiri (George Bush, Senior) yang terkenal dengan perang teluknya. Hampir dapat dipastikan, perilaku anaknya Bush muda sangat dipengaruhi oleh sang ayah, terlebih sang ayah mempunyai masalah serius dengan lawan. Mendasarkan pada teori pertanggungjawaban tersebut dan banyaknya penderitaan yang dialami rakyat Irak, maka sudah seharusnya dan sepantasnya komando tertinggi atau sebagai inisiator serangan ke Irak yaitu AS yang dalam hal ini George Bush bertanggung jawab sebagai penjahat perang.

\section{Penutup \\ Simpulan}

Berdasarkan uraikan di atas dapat disimpulkan bahwa HHI bersumber pada Konvensi Je- 
newa 1949, dilengkapi dengan Protokol Tambahan I dan II Tahun 1977, serta Konvensi Den Haag 1907 yang masing-masing mengatur tentang perlindungan korban perang/konflik bersenjata serta alat dan cara/metode yang boleh digunakan dalam berperang agar perang dapat manusiawi, dalam arti tidak menimbulkan penderitaan yang berlebihan. Sementiara para pihak yang terlibat dalam perang/konflik bersenjata internasional/non internasional harus menghormati prinsip-prinsip pembatasan, proporsionalitas dan prinsip pembedaan dalam perang. Apabila mereka melakukan tindakan melanggar HAM berat harus menanggung risikonya sebagai penjahat perang yang harus diadili dan dijatuhi pidana sebagai upaya penegakan hukum berdasarkan yurisdiksi yang berlaku bagi mereka dan juga berdasarkan pada pertanggungjawaban komando. Mekanisme penegakan hukum terhadap para pelaku kejahatan pidana internasional tersebut dalam $\mathrm{HHI}$ dilakukan dengan melalui tiga macam mekanisme yaitu pertama menurut Konvensi Jenewa 1949, atau melalui peradilan yang bersifat sementara (peradilan ad hoc), dan melalui Mahkamah Pidana Internasional (ICC).

Konsekuensi Indonesia sebelum menjadi anggota ICC adalah terlebih dahulu Indonesia harus melakukan proses sinergi hukum nasionalnya dengan ketentuan-ketentuan dalam Statuta Roma yang meliputi hukum pidana, hukum acara pidana, ekstradisi, pengadilan pidana dan Undang Undang HAM itu sendiri.

Hal ini dilakukan agar tujuan akhir dapat tercapai dengan baik yaitu menjadikan Statuta Roma sebagai kepanjangan sistem dari yurisdiksi nasional Indonesia, menghindari konflik antara Statuta Roma dengan hukum Indonesia, dan menciptakan prosedur hukum internal bagi Indonesia ketika yurisdiksi ICC berlaku di Indonesia.

\section{Saran}

Langkah yang harus dilakukan Indonesia, antara lain melakukan revisi seluruh peraturan terkait kedaulatan dan komplementaritas seperti ne bis in idem, penyerahan subjek hukum kepada ICC, masalah imunitas, disparitas pemidanaan, dan membuat satu Undang-Undang kerjasama (Cooperation Act) dengan ICC.

\section{Daftar Pustaka}

Adjis, Chairil Anwar. "Peradilan Internasional Versus Bush: Studi Kasus State Violence", Jurnal Kriminologi Indonesia. Vol. 3 No. 1 Edisi Juni 2012. Jakarta: Departemen Kriminologi UI;

Agusman, Damos Dumoli. “Dasar Konstitusional Perjanjian Internasional Mengais Latar Belakang Dan Dinamika Pasal 11 UUD 1945”. Opinio Juris, Vol. 4 Edisi Januari April 2012. Jakarta: Penerbit Direktorat Jenderal Hukum dan Perjanjian Internasional Indonesia;

Akhavan, Payam. "The Lord's Resistance Army Case: Uganda's Submission of the First State Referral to the International Criminal Court". American Journal of International Law. Vol. 99 Edisi April 2005, Washington: American Society of International Law;

Al-Yasa, Abubakar. "Prinsip-prinsip Hukum Humaniter dalam Hukum Islam". Jurnal Ilmu Hukum Kanun. Vol. 9 No. 241999. Aceh: Penerbit Fakultas Hukum Universitas Syiah Kuala;

Anshari, Natsri. "Tanggung Jawab Komando Menurut Hukum Internasional Dan Hukum Nasional Indonesia" Jurnal Hukum Humaniter. Vol. 1 No. 1 Edisi 2005, Jakarta: Penerbit Pusat Studi Hukum Humaniter dan HAM Universitas Trisakti;

Ariadno, Melda Kamil. "Kedudukan Hukum Internasional Dalam Sistem Hukum Nasional". Jurnal Hukum Internasional. Vol. 5 No. 3 Edisi 2008, Jakarta: Lembaga Pengkajian Hukum Internasional UI;

Dewanto, Wisnu Aryo. "Memahami Arti Undangundang Pengesahan Perjanjian Internasional di Indonesia". Jurnal Opinio Juris. Vol. 4 Edisi Januari-April 2012, Jakarta: Direktorat Jenderal Hukum dan Perjanjian Internasional;

"Status Hukum Internasional dalam Sistem Hukum di Indonesia". Jurnal Mimbar Hukum. Vol. 21 No. 2 Edisi 2009, Yogyakarta: Fakultas Hukum UGM;

Cahyono, Heru. "Kejahatan Perang yang Diatur dalam Hukum Internasional dan Hukum Nasional”. Jurnal Hukum Humaniter, Vol. 
1 No. 1 Edisi 2005. Jakarta: Pusat Studi Hukum Humaniter dan HAM Universitas Trisakti;

Ismail, Isplancius. 2011. Konsep Dasar Hukum Internasional. Purwokerto: UPT Percetakan dan Penerbitan Unsoed;

Kalshouven, Frits. 1991. Constraint on The Waging of War, Jenewa: ICRC, Swizterland;

Kusuma, Mulyana W,. 1990. Analisa Kriminologi Tentang Kejahatan-Kejahatan Kekerasan. Jakarta: Ghalia Indonesia.

Novianti. "Implikasi Ratifikasi Protokol Kyoto Terhadap Pengelolaan Hutan Indonesia" Percikan. Vol. 109 Edisi 2010. Bandung: Penerbit Ikatan Keluarga Besar Universitas Jambi;

Pangaribuan, Aristo. 2013. Perdebatan Menuju Mahkamah Pidana Internasional (International Criminal Court). Jakarta: Penerbit Papas Sinar Sinanti dan Badan Penerbit FH UI;

Permanasari, Arlina Permanasari dkk. 1999, Pengantar Hukum Humaniter Internasional, Jakarta: Penerbit ICRC;

Pictet, Jean, 1985, Development and Principles of International Humanitarian Law, Jenewa: Martinus Nijhoff Publisher;

Ridwan, Nurdin. "Perlindungan Korban Perang Menurut Hukum Humaniter Dan Hukum Islam”. Jurnal Ilmu Hukum Kanun. Vol. 9 No. 24 Edisi 1999. Aceh: Penerbit Fakultas Hukum Universitas Syiah Kuala;

Savitri, Dewi. “Kejahatan Perang oleh Jepang: Studi Kasus terhadap Jugung lanfu Sebagai Hegemoni Kebudayaan di Indonesia Periode 1942-1945". Jurnal Kriminologi Indonesia. Vol. 6 No. 3 Edisi 2010. Jakarta: Departemen Kriminologi UI;

Sefriani. “Ketaatan Masyarakat Internasional Terhadap Hukum Internasional Dalam Perspektif Filsafat Hukum" Jurnal Hukum. Vol. 18 No. 3 Edisi 2011. Yogyakarta: Fakultas Hukum Universitas Islam Indonesia;

Siswanto, Arie. 2005. Yurisdiksi Material Mahkamah Kejahatan Internasional. Jakarta: Ghalia Indonesia;

Sondakh, Devy. “Aspek-aspek Hukum Humaniter Dalam Kejahatan Perang Yang Dilakukan Oleh Anggota Dinas Angkatan Laut Dalam Konflik Internasional". Jurnal Hukum Humaniter. Vol. 4 No. 7 Edisi 2008.
Jakarta: Penerbit Pusat Studi Hukum Humaniter dan HAM Universitas Trisakti;

Suryokusumo, Sumaryo. "Agresi Dalam Perspektif Hukum Internasional”. Jurnal Hukum Internasional. Vol. 3 No. 1 Edisi 2005. Jakarta: Penerbit Lembaga Pengkajian Hukum Internasional Universitas Indonesia;

Supancana. "Kemungkinan Meratifikasi Protocol of Space Asset: Pertimbangan Dan Implikasinya Kepada Kepentingan Nasional". Jurnal Analisis Dan Informasi Kedirgantaraan. Vol. 4 No. 1 Edisi 2007. Jakarta: Penerbit Lembaga Penerbangan dan Antariksa Nasional;

Trihoni, Harianja Nalesti. "Pertanggungjawaban Pidana Secara Individual bagi Pelanggaran Hukum Humaniter dalam Konflik Bersenjata Internal". Jurnal Hukum Respublica. Vol. 3 No. 2 Edisi 2004. Pekanbaru: Fakultas Hukum Universitas Lancang Kuning;

Thontowi, Jawahir. "Pelanggaran HAM Berat" Jurnal Hukum. Vol. 14 No. 2 Edisi 2004, Jakarta: Penerbit Fakultas Hukum Universitas Islam Sultan Agung;

Yulianto, Achmad. "Penempatan Pasukan Amerika Serikat di Selat Malaka Perspektif Hukum Internasional". Jurnal Media Hukum. Vol.12 No.1 Edisi 2005. Yogyakarta: Penerbit Fakultas Hukum Universitas Muhammadiyah Yogyakarta;

Yuniati, Sri. "Hukum Humaniter Internasional Atas Kejahatan Perang”. Jurnal Ilmu Sosial Dan Ilmu Politik Aspirasi. Vol. 16 No. 1 Edisi 2006, Jember: Fakultas Ilmu Sosial dan Ilmu Politik Universitas Jember. 